\title{
Use of the Micronucleus Test on Tradescantia (Trad-MCN) to Evaluate the Genotoxic Effects of Air Pollution
}

\author{
José Roberto Cardoso Meireles and Eneida de Moraes Marcílio Cerqueira \\ Feira de Santana State University \\ Brazil
}

\section{Introduction}

Good air quality is the fundamental condition for maintaining the equilibrium of human health and ecosystems. However, starting at the time of the industrial revolution, human action has progressively introduced into the atmosphere compounds and particles that compromise the harmony of life on our planet: a process that is known as atmospheric pollution.

Thus, atmospheric pollution is defined as the result from excessive introduction of compounds and particles into the air layers that surround Earth (Marcondes, 1993). There are now many sources of atmospheric pollution, and prominent among these are industrial plant, factories and automotive vehicles powered by gasoline and diesel. Among the many pollutants that compromise air quality, particularly in large urban centers, are sulfur dioxide $\left(\mathrm{SO}_{2}\right)$, carbon monoxide $(\mathrm{CO})$, nitrogen oxides, particles and aromatic polycyclic hydrocarbons, which can combine to form other compounds such as ozone and peroxyacetyl nitrate, thereby giving rise to a complex mixture of pollutants in the atmosphere.

The presence of these compounds in the air causes a variety of human health problems, such as abnormalities of the respiratory and cardiovascular systems, allergic reactions and development of lung and tracheal cancer (Brunekreef et al., 2002; Perera et al., 2002; Traversi et al., 2008).

Cancer is a disease that results from abnormalities in genes involved in controlling cell proliferation and differentiation and/or genes involved in DNA repair mechanisms and in inducing apoptosis (Hanahan \& Weinberg, 2000). The association between atmospheric pollution and cancer therefore comes from the fact that many of the contaminants are mutagens, i.e. they are agents capable of inducing both point mutations (abnormalities involving only one or very few DNA bases) and chromosome aberrations (abnormalities that compromise the structure or the number of chromosomes).

\section{Genotoxic effects of atmospheric pollution}

Mutagenic effects from atmospheric contaminants have been demonstrated by many authors using different methodologies, both in vivo and in vitro, such as DNA adduct 
detection (Peluso et al., 2008), comet test (Ianistcki et al., 2009; Kawanishi et al., 2009), sister chromatids exchanges (SCE) and micronuclei (Kawanishi et al., 2009), identification of gene mutations in mice (Yauk et al., 2008) and Ames test (Coronas et al., 2008; Traversi et al., 2009).

Peluso et at. (2008) evaluated air genotoxicity among 79 workers at the MIE industrial complex (one of the largest steel and oil refinery industrial complexes in Southeast Asia) and among 72 people living nearby. Fifty individuals living in an area without industrial pollution were evaluated as controls. Peripheral lymphocytes were analyzed by means of the ${ }^{32} \mathrm{P}$-postlabeling technique in order to identify DNA adducts, i.e. structures formed through covalent bonding of molecules to the DNA. The DNA adduct levels were significantly greater among the workers and individuals living close to the industrial complex than among the controls, thus demonstrating the potential that atmospheric pollution has for inducing mutations.

Greater occurrence of damaged DNA consequent to exposure to polycyclic aromatic hydrocarbons (PAHs) present in the atmosphere was observed by Ianistcki et at. (2009) through using the Comet test on Helix aspersa Müller, 1774. This study was conducted in areas of the metropolitan region of Porto Alegre (Brazil) where the atmosphere is contaminated with PAHs. Between the two fractions of particulate matter that were isolated (particles measuring between $2.5 \mu \mathrm{m}$ and $10 \mu \mathrm{m}$ in diameter and particles of diameter less than $2.5 \mu \mathrm{m}$ ), greater genotoxicity was observed consequent to exposure to the particles of smaller diameter, which may be related to greater absorption of these particles. Kawanaka et at. (2011) observed that ultrafine particles are deposited more efficiently in the alveolar region of human lungs than are larger particles. Thus, ultrafine particles play an important role as carriers of mutagenic agents.

Kawanishi et at. (2009) evaluated the genotoxicity of 3,6-dinitrobenzo[e]pyrene, a novel mutagen in ambient air and surface soil, in vitro and in vivo. Human cells of the HepG2 human lineage were analyzed regarding the frequencies of exchanges between sister chromatids and occurrences of hprt mutations and micronuclei, and the Comet test was used to evaluate occurrences of damaged DNA in IRC mice. A genotoxic effect caused by 3,6dinitrobenzo[e]pyrene was observed in all the trials.

Yauk et at. (2008) also described damage to DNA, as seen through greater occurrences of gene mutations, in germinative cells from mice exposed to atmospheric pollution without protection. They observed that spermatozoid mutations were 1.6 times more frequent in these exposed animals than in animals whose exposure was diminished through using highefficiency particulate-air (HEPA) protection. Furthermore, they identified high levels of DNA hypermethylation in spermatozoids from the exposed animals, which in their view, might have wide-ranging repercussions on chromatin structure, gene expression and genome stability. Genotoxic effects from atmospheric contaminants have also been shown using the Ames test (Coronas et al., 2008; Traversi et al., 2009).

The proven mutagenic action of atmospheric pollutants is the basis for the biological plausibility of epidemiological studies that have revealed associations between some types of cancer, especially lung cancer, and atmospheric pollution (Beelen et al., 2008; Eitan et al., 2010; Kapka et al., 2009; Trédaniel et al., 2009; Vineis et al., 2007).

Air quality monitoring therefore becomes essential and, within this context, the use of biological tests capable of detecting gene mutations or chromosome damage is considered to be an important preventive medical measure. Such tests are also effective for detecting the 
additive and synergistic effects of air pollutants, unlike chemical analyses, which evaluate the action of a given genotoxic agent in isolation (Cohen et al., 2002; Wada et al., 2001).

Bioassays developed using plants and clones of the genus Tradescantia are considered to be valuable tools for assessing the mutagenic effects of environmental contaminants. For this reason, since the beginnings of genetic toxicology, they have been widely used in studies and biomonitoring programs.

\section{Evaluation of the genotoxicity of atmospheric pollution using plants and clones of the genus Tradescantia}

Carvalho (2005) highlighted several characteristics of higher plants that qualify them for use in environmental biomonitoring. These include the following:

- Just like human cells, higher plant cells are eukaryotic and present organization of the genetic material that resembles that of humans;

- Also in common with humans, higher plants present germinative and somatic cell lines that go through meiotic and mitotic cycles, respectively;

- Many higher plants present short reproductive cycles;

- Higher plants can be propagated vegetatively, thus ensuring genetic purity, which also favors the perpetuation of hybrids;

- Studies on the use of higher plants can be conducted both in situ and in the laboratory. According to Alves et al. (2001), plants are generally more sensitive to pollution than animals are, which makes them particularly suitable for biomonitoring studies on atmospheric pollution.

\subsection{The genus Tradescantia}

Tradescantia is a genus of perennial herbaceous plants in the family Commelinaceae. It originates from the New World and comprises around 500 species with distribution going from southern Canada to northern Argentina (Watson \& Dallwitz, 1992). In the 17th century, they were introduced into Europe, where they are used for ornamentation, just as they are used in most other countries.

The height of the plants varies in most species between $30 \mathrm{~cm}$ and $60 \mathrm{~cm}$, and its ovalshaped leaves are distributed along the stem. The inflorescence, which may be axillary or terminal, is protected by bracts that may or may not be differentiated from the leaves. The flowers present radial symmetry and are hermaphroditic. The pedicles vary in size between the species, and the calyx and corolla are formed, respectively, by three sepals and three petals. The stamens are free and there are six of them, and the anthers have two thecae. The gynoecium has a trilocular sessile ovary, and each locule holds two ovules. The style is simple and the stigma is capitate. In most of the species, the fruits present a capsule with a locus, and each locus holds two seeds.

Plants and clones of the genus Tradescantia have been used for environmental monitoring since the time of the first studies investigating the mutagenic activity of chemical and physical compounds, in relation to components of the atmosphere, soil or water. In addition to its high sensitivity to mutagen action, its ease of cultivation, short life cycle and, especially, its large chromosomes that are few in number are characteristics that make plants and clones of the genus Tradescantia valuable instruments for environmental monitoring (Ma \& Grant, 1982). 


\subsection{Species and clones of the genus Tradescantia used in genotoxicity bioassays}

Most of the studies using Tradescantia plants, and particularly those developed in Europe, have been conducted using clone 4430, which is a diploid hybrid between T. hirsutiflora Bush (2461C), with a blue flower, and T. subacaulis Bush (2441), with a pink flower (Isidori et al., 2003; Klumpp et al., 2006; Ma et al., 1996). This clone, which was developed by Sparrow et al. in 1960, is very versatile and has, since then, been widely cultivated indoors, although it requires special conditions for it to grow and flower. On the other hand, it presents great sensitivity to the action of chemical and physical mutagens in the environment. Because it is sterile, it has the advantage that its genetic uniformity is maintained. It can be used both for the micronucleus test (Trad-MCN) and for the stamen hair mutation test (Trad-SHM).

The Tradescantia species most frequently used for carrying out Trad-MCN is T. pallida (Rose) Hunt. cv. purpurea Boom (Figure 1). This is a small-sized herbaceous plant (reaching a maximum height of $25 \mathrm{~cm}$ ) with spear-shaped succulent leaves that is native to North America and Central America (Mexico and Honduras) (Lorenzi \& Souza, 2008). The epidermis of the leaves presents large quantities of anthocyanin, which gives them a purple color, particularly in very bright light (Joly, 1998). Two large canoe-shaped bracts protect the inflorescence, which presents pink flowers.

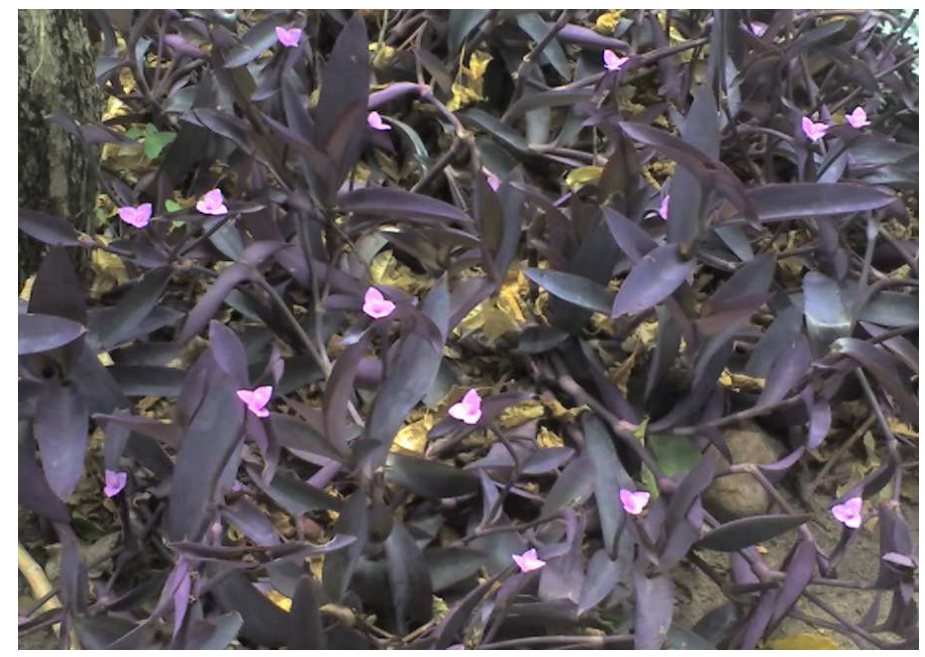

Fig. 1. Tradescantia pallida

Although this species has sexual reproduction, its genetic uniformity can be ensured by means of vegetative propagation from a single stalk. It has shown sensitivity to the action of environmental mutagens resembling that of 4430 and \#03 (Andrade Jr et al., 2008; Batalha et al., 1999; Guimarães et al., 2000; Meireles et al., 2009; Suyama et al., 2002). This species has been greatly used in studies conducted in South America because of the great adaptability of these plants to the climatic conditions of South American countries, unlike clone 4430, which is difficult to cultivate under these conditions. In addition, using plants that develop under natural conditions reduces the costs of the study and minimizes any problems of pest attacks, given that these plants are already biologically adapted to the environment (Rodrigues et al., 1997). 


\subsection{Genotoxicity bioassays using Tradescantia}

Tests carried out using plants or clones of the genus Tradescantia, like most plant bioassays, are considered to be type II mutagenesis tests (Ennever et al., 1988), since they present high sensitivity and low specificity.

Four tests for assessing environmental genotoxicity have been developed using Tradescantia. One of these, the stamen hair mutation test (Trad-SHM) detects occurrences of point mutations. This test is carried out using clone 4430 and is based on the occurrence of recessive mutation that results in changing the blue color of stamen hairs to pink (Emmerling-Thompson \& Nawrocky, 1982). It was first used to assess the genotoxic effects from ionizing radiation and, at the start of the 1970s, it was proposed that the test should be applied in studies on chemical mutagenesis (Underbrink et al., 1973). Additional studies using Trad-SHM to assess the genotoxic effects of chemical substances reconfirmed the high sensitivity that had previously be observed with this test in studies on radiation (Ma et al., 1994; Shima \& Ichikawa, 1994). Trad-SHM has now been used for assessing mutagenicity in relation to both atmospheric and water pollution (Arutyunyan et al., 1999; Grant et al., 1992).

The other tests using Tradescantia that have been developed for environmental biomonitoring are cytogenetic studies based on occurrences of changes to the number and/or structure of the chromosomes: root-tip mitosis and pollen tube tests and the micronucleus test on tetrads of Tradescantia (Trad-MCN). In assessments on the genotoxic action of atmospheric pollutants, the main test used is Trad-MCN, which is the focus of the present chapter.

\section{The micronucleus test on tetrads of Tradescantia (Trad-MCN)}

\subsection{Fundamentals and development}

The micronucleus test on tetrads of Tradescantia (Trad-MCN) is currently the most widely used bioassay on plants for detecting genotoxins in the environment. According to a recent paper, approximately 160 chemicals have so far been tested and 100 articles on complex environmental mixtures have been published (Misík et al., 2011).

Trad-MCN consists of a set of procedures for exposing plants of the genus Tradescantia to contaminating agents, culminating in estimates of the micronucleus frequencies in mother cells of pollen grains at the tetrad phase. Micronuclei are structures that result from whole chromosomes or fragments of chromosomes that, because they do not bind to the spindle fibers, are not included in the nuclei of the daughter cells. Instead, they remain in the cytoplasm of the interphase cells, where they are observed as corpuscles resembling the nucleus, measuring $1 / 3$ to $1 / 5$ of the size of the nucleus. Since micronuclei result both from chromosomal fragments and whole chromosomes lagging behind in anaphase, they reveal the clastogenic and/or aneugenic action of a given mutagen (Holland et al., 2008) (Figure 2). Estimation of the numbers of micronuclei in tetrads of Tradescantia was first proposed at the end of the 1970s, in a pioneering study conducted by Ma and coworkers (Ma et al., 1978). In that study, they used clone 4430 to compare the formation of micronuclei in tetrads (Trad$\mathrm{MCN}$ ) with stamen hair mutations in cells (Trad-SHM), after exposing the plants to 1,2dibromoethane (DBE). The results obtained revealed that the sensitivity of Trad-MCN was approximately 30 times greater than that of Trad-SHM. The greater sensitivity of Trad-MCN in relation to Trad-SHM has been observed in several other studies, such as Gichner \& Velemínnský (1999); Minouflet et al. (2005). 


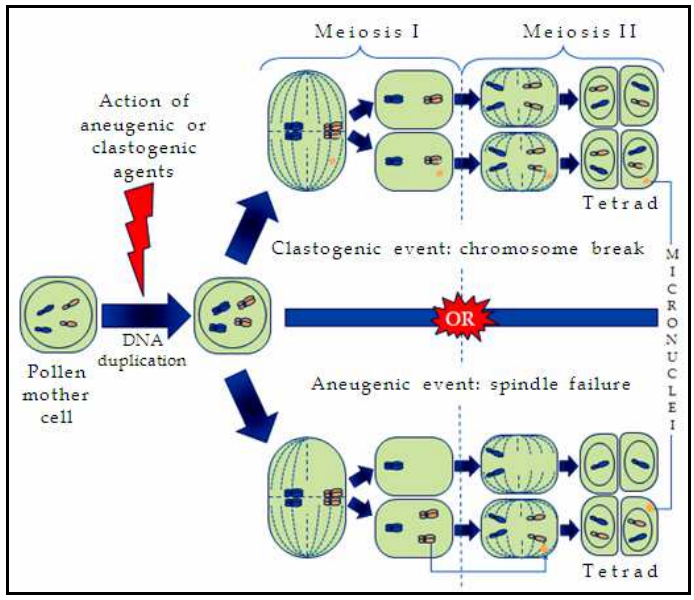

Fig. 2. Diagram of micronucleus formation

\subsection{Methodology}

\subsubsection{Cultivation and maintenance of Tradescantia plants}

The cultivation and maintenance conditions for Tradescantia plants depend primarily on the climatic conditions under which the study will be developed. In countries with a temperate climate, the plants can be cultivated in greenhouses, growth chambers or outdoors. In countries with a very rigorous winter, the cultivation should be undertaken in greenhouses or growth chambers. It is important to control the ventilation, temperature and air quality conditions, since these are factors that may induce occurrences of micronuclei. According to Klumpp et al. (2004), at a temperature of $11^{\circ} \mathrm{C}$ the frequency of spontaneous occurrence of micronuclei is 100 times greater, while exposure at a temperature of $42^{\circ} \mathrm{C}$ is incompatible with development of the mother cells of pollen grains. The ideal cultivation conditions consist of day/night temperatures of $21 / 19 \pm 0.2^{\circ} \mathrm{C}$, day/night relative humidity of $65 / 70 \%$ and a daylight cycle of $17 \mathrm{~h}$ (Rodrigues, 1999). The substrate composition should consist of fertile soil with good drainage, which can be achieved by adding coarse sand and standardized organic matter to the soil. Commercially marketed soils such as ED73 can also be used (Klumpp et al., 2006). In addition to watering the soil, which should be done on alternate days, monthly use of fertilizers is recommended (NPK).

Following these procedures is the essential prerequisite for obtaining plants in numbers and quality that are sufficient to ensure that the study can be conducted and that the results will be reliable.

\subsubsection{Exposure of the plants}

When the genotoxicity of atmospheric pollutants is evaluated in situ, this involves exposing plants that have been cultivated under the conditions described above and been transported to the location under investigation (active monitoring), or it is done on plants in gardens, public squares and streets that were already planted out in these locations for ornamental purposes (passive monitoring).

In active monitoring, at least 15 plants per monitoring point are exposed for time periods that vary according to the protocol, depending on the degree of contamination at the 
location investigated. Fomin \& Hafner (1998) considered that exposure for a six-hour period was insufficient for detecting genotoxic effects and suggested that the exposure duration should be between 10 and $24 \mathrm{~h}$. Ma et al. (1996) also considered that a five to seven-hour period was insufficient for detecting genotoxic effects and recommended that the exposure duration should be between 24 and $30 \mathrm{~h}$.

In biomonitoring the atmosphere, it is important that the overall duration of the study should not be short, given the variations in pollution levels that may occur according to how the weather varies across the different seasons. From our experience, we consider that 12 months is a period that more faithfully reflects the real effects of atmospheric pollution. To avoid contamination by soil pollutants, the vases containing the plants should be kept on stands at a height of between $1 \mathrm{~m}$ and $2 \mathrm{~m}$. Figure 3 shows the dimensions of the stands that have been used in studies developed by researchers at our laboratory.

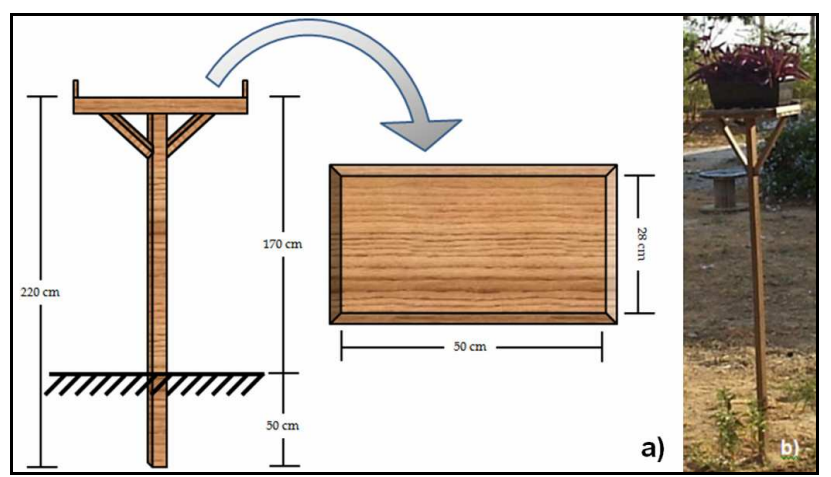

Fig. 3. Dimensions of the stands (a) and photography exposure mode (b)

The records in the literature reveal that the way in which plants have been exposed has varied greatly between the protocols adopted, according to the objectives and characteristics of each study, although this does not compromise the validity of the test.

Evaluations on the genotoxicity of atmospheric particles using Trad-MCH can be carried out in a laboratory, starting from air samples collected in glass fiber filters using a high-volume PM-10 sampler. The filter mesh used can be of different sizes in order to allow particle separation according to size. Exposure of the inflorescences (between 15 and 20 of them) can be done by immersing them for $24 \mathrm{~h}$ in distilled water containing particle extract dissolved in dimethyl sulfoxide (DMSO).

Negative control plants should always be included in all protocols, i.e. plants grown in pollution-free areas and/or treated with distilled water or another compound that is known to be non-mutagenic, such as DMSO. A positive control, consisting of exposing plants to a known genotoxin, may also be included.

In assessing the genotoxicity of atmospheric pollutants, whether done through active monitoring or done through exposure in a laboratory, it is important to take the recovery time into consideration, i.e. the length of time after the exposure that is needed for the meiocytes to go from prophase I to the tetrad phase. This is the time taken for the meiotic cycle to run its course, and it will ensure that the damage induced from prophase I onwards will be observed in a sufficiently large number of cells. Therefore, the duration of meiosis in the Tradescantia plant or clone used in the test needs to be known: the closer the length of the 
recovery period is to the time taken for meiosis to occur, the greater the chance is that the damage induced through the exposure will be detected. Falistocco et al. (2000) observed that the duration of meiosis for clone 4430 was $84-86 \mathrm{~h}$ and they therefore suggested that if the recovery time of $24 \mathrm{~h}$ used in many protocols was insufficient to observe any damage, the experiment should be repeated with a longer recovery time.

\subsubsection{Selection and preparation of inflorescences}

The protocol for selecting and preparing inflorescences that is used in many Trad-MCN studies is the one proposed by Ma (1981). This protocol prescribes that young inflorescences should be collected and, after a recovery period of 24-30h, they should immediately be fixed in an acetic-alcohol solution (1:3). After $24 \mathrm{~h}$ of fixing, the inflorescences are transferred to $70 \%$ ethanol and kept refrigerated $\left( \pm 6^{\circ} \mathrm{C}\right)$ until the time of slide preparation.

To prepare the slides, the inflorescences are dissected with the aid of a surgical probe under a stereo microscope, in order to isolate the flower buds. Once the buds have been isolated, they are arranged in order of size and the one in the middle of the size range is selected first. This bud is transferred onto a glass slide and is dissected with the aid of a surgical probe, under a stereo microscope, in order to expose the anthers. After discarding the fragments of the bud, the anthers are macerated using a glass rod and drops of acetocarmine $(2 \%)$ are added. After the maceration has been completed, a coverslip is placed on top of the preparation, which is then quickly heated up using a glass alcohol lamp $\left(80^{\circ} \mathrm{C}\right)$. The coverslip is pressed down using finger pressure and then the preparation is placed under a microscope to identify whether there are sufficient numbers of tetrads. The steps for preparing the slides are presented in Figure 4. After confirming that there are enough tetrads, the slide is considered to be suitable for analysis and the other flower buds are discarded. If there are not enough tetrads, the procedure is repeated with another bud, and so on.

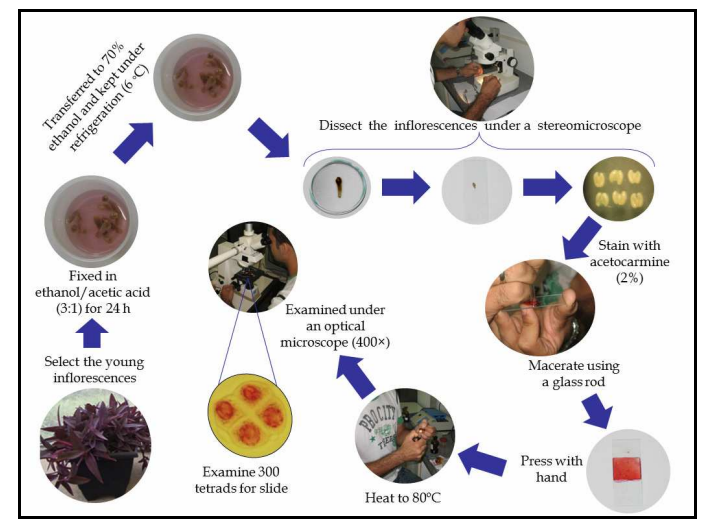

Fig. 4. Steps for preparing the slides

\subsubsection{Cytogenetic analysis}

The cytogenetic analysis for estimating the number of micronuclei is done under an optical microscope (400X). It should include counting 300 tetrads (Figure 5a) per slide and, for each exposure, five slides from individual inflorescences should be prepared, thus totaling 1,500 
tetrads per treatment. It is important to code the slides so that the analysis can be done blindly. They should only be decoded after finishing the cytogenetic analysis.

Structures measuring $1 / 3$ to $1 / 5$ of the sized of the nucleus, with similar chromatin distribution and distinct separation from the nucleus, are taken to be micronuclei (Figure $5 b)$.
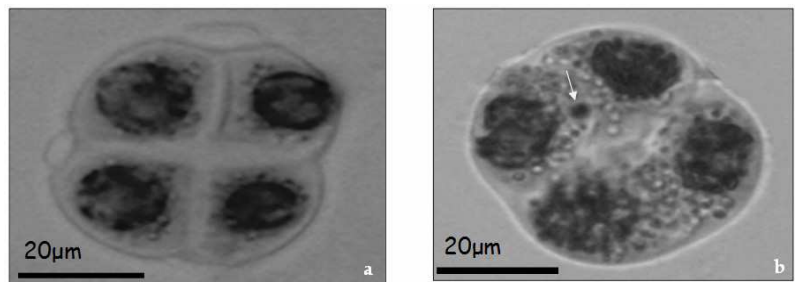

Fig. 5. Photomicrograph of tetrad of Tradescantia pallida with and without micronuclei (arrow)

\subsubsection{Statistical analysis}

The results obtained using Trad-MCN should always be subjected to adequate statistical analysis. Several tests can be used, for example Dunnet's test, Student's $t$-test and KruskalWallis test.

\subsection{Advantages and disadvantages of Trad-MCN}

Trad-MCN is a fast, simple and low-cost test that generates reliable results. Micronuclei are observed under an optical microscope and are easily identified. The plants are easy to cultivate, occupy little space and develop satisfactorily throughout the year, in the open air in subtropical regions and in greenhouses anywhere. The test is considered to be versatile, since it enables genotoxic evaluations on pollutants both in situ and in a laboratory, and because it is sensitive to contaminants of gaseous, liquid and radioactive nature, thus enabling biomonitoring of the soil, water and atmosphere.

The sterility of Tradescantia clones and the capacity of these plants for vegetative propagation eliminates the variation coming from meiotic recombination, thereby ensuring that genetic uniformity is maintained (which would be lost through this process). In addition, meiotic chromosomes are more sensitive to mutagens than mitotic chromosomes are (Rodrigues, 1999). Metabolism of pre-carcinogens into carcinogens occurs mostly in the plant itself, and enzyme activation is unnecessary.

Inflorescences of Tradescantia can be fixed and stored for subsequent cytological observation for long periods. The cytological preparations can also be stored for future studies.

The main limitation of Trad-MCN is that counting the micronuclei constitutes an underestimate of the real occurrence of genetic damage, given that chromosome rearrangements (translocations, inversions, etc.) are not detected. Because the test is highly sensitive, special care is required to ensure that the spontaneous micronucleus frequency is not altered by the action of agents other than those under investigation. In addition, the micronucleus frequency undergoes variations depending on climatic conditions. The mutagenic effects observed through the test cannot be directly associated with carcinogenicity, and the differences between plant and animal metabolism have to be taken into account, which limits the ability to extrapolate from the results (Ma, 1981). 


\subsection{Detection of atmospheric pollution using Trad-MCN}

Plants and clones of Tradescantia are particularly sensitive to chemical mutagens, especially those that are present in the atmosphere. For this reason, they have been extensively used for biomonitoring of atmospheric pollution, in order to assess the genotoxic effects of gases and particles that are generated through the activity of factories, industrial plant, incinerators and landfills, and through burning fossil fuels.

\subsubsection{Tradescantia clones}

Ma et al. (1996) conducted a study in which the aim was to evaluate the genotoxic effects from atmospheric pollution generated through gas emissions consequent to the processes of dumping garbage in landfills and garbage incineration. They investigated occurrences of mutations in stamen hairs (Trad-SHM) and the micronucleus count in tetrads (Trad-MCN) in plants of clone 4430 that were exposed in the vicinity of a landfill and an incinerator (in situ biomonitoring) and in a laboratory. Four gases are emitted in such processes: toluene, ethylbenzene, trichloroethylene and ethyltoluene. For each test, two controls were analyzed: one kept in the laboratory and the other in the field. The observed frequency of stamen hair mutations, but not the frequency of micronuclei in tetrads, was significantly greater in the plants exposed in the landfill, in comparison with both of the controls. The average pink mutation rates and micronucleus frequencies in the incinerator tests were borderline positive. The authors considered that these results might be due to the length of exposure of the plants: not only was this short (5-7h), but also it did not include times of the day (early morning and late afternoon) when the wind died down. The results obtained from exposure of plants in the laboratory showed higher frequencies of micronuclei, but not of stamen hair mutations, in all the tests. This showed that both the landfill and the incinerator processes generated gases with relatively high genotoxicity.

The genotoxicity of the gases emitted by incinerators was also evaluated by Fomin \& Hafner (1998) using Trad-MCN with three different approaches: a) direct fumigation of Tradescantia with diluted incinerator emissions; b) exposure of Tradescantia to smoke condensates; and c) in situ monitoring of genotoxicity of emissions near a municipal incinerator. The results obtained from direct fumigation of the plants and exposure to smoke condensates showed that the micronucleus frequencies in the exposed plants were significantly greater. The results of in situ monitoring of genotoxicity near a municipal waste incinerator showed that the Tradescantia micronucleus frequencies depended on the distance from the incinerator, and the direction of wind.

Misík et al. (2007) used plants of clone \#03 to evaluate the genotoxicity of the urban pollution caused by an incinerator and a petrochemical plant in the city of Bratislava (Slovakia). The plants were placed at distances of $150 \mathrm{~m}$ and $200 \mathrm{~m}$ from the incinerator and petrochemical plant, respectively. During the period in which the first data were gathered (1997 to 2000), the micronucleus frequencies in the exposed plants were significantly higher than the frequencies observed in the control plants, but no difference in micronucleus occurrence was detected in the plants collected between 2003 and 2005.

These authors considered that the observed reduction in genotoxicity was due to the substantial reduction in atmospheric pollution that had been brought about through using new technologies. Reductions in the genotoxicity of the air caused by installation of protective measures had previously been observed by Fomin \& Hafner (1998).

Rodrigues et al. (1996) showed that Trad-MCN, but not Trad-SHM, was effective for detecting the mutagenic effects of ozone, even at low concentrations. In fumigation 
chambers, these authors subjected plants of clone 4430 to doses of 50 and $100 \mathrm{ppb}$ for $6 \mathrm{~h}$, over periods of 1-3 days. Higher frequencies of micronuclei, but not of mutations in stamen cells, were observed in relation to the control group.

Monarca et al. (1999) evaluated the air quality in Brescia (Italy) in a study that included in situ biomonitoring and laboratory analysis on the genotoxic effects of particulate matter collected from the air of that city. In the laboratory, young Tradescantia inflorescences were kept for $24 \mathrm{~h}$ in $1 \mathrm{ml}$ of distilled water containing extracts of particulate matter dissolved in dimethyl sulfoxide (DMSO). These samples had been gathered from two streets in the city: one residential and the other, with heavy traffic. As a control, the plants were kept for the same length of time in distilled water and DMSO. The results from the laboratory exposure to particulate matter from the street with heavy traffic indicated that the micronucleus frequency was greater than in the control plants. In the in situ monitoring, the plants were placed in three areas of Brescia for 24h: area A, a link road in a heavily industrialized district; area B, a bypass around the town center; and area $\mathrm{C}$, the square in front of the railway station. The results from the in situ biomonitoring did not, however, show any increased micronucleus frequencies.

Mutagenic effects from pollution originating from gasoline and diesel combustion in automotive vehicles were also investigated by these authors in a tunnel in the city of Perugia with heavy traffic movements and another in the city of Brescia with moderate traffic. Although the lengths of exposure of the plants in the tunnel in Perugia ( $1 \mathrm{~h}$ and $5 \mathrm{~h}$ ) were shorter than those of the plants in the tunnel in Brescia (24h), higher micronucleus frequencies than in the control plants were only observed in the plants exposed in the Perugia tunnel. These authors concluded that in situ monitoring using Trad-MCN only seemed to be effective when the pollution levels were high.

Villarini et al. (2009) also conducted a monitoring study on atmospheric pollution in Perugia, using Trad-MCN and the Comet test on Nicotiana tabacum cv. Xanthi. These authors analyzed three urban sites in the city with different levels of pollution. The length of exposure was $24 \mathrm{~h}$ and the sites were monitored five times: twice in the winter and once each in the spring, summer and autumn. The plants exposed in the area with greatest pollution were the ones that presented the highest micronucleus frequencies. Trad-MCN showed a better correlation with the pollution levels than did the Comet test.

The genotoxic effects from atmospheric pollution that are detected by Trad-MCN depend on the season of the year in which the plants are exposed, among other factors (Isidori et al., 2003). These authors exposed plants of clone 4430 at 17 sites in the city of Caserta (southern Italy), with a variety of traffic levels, during both the winter and the summer. Comparison with the control group revealed micronucleus frequencies that were significantly higher in the plants exposed during the winter, at all the sites, and at only two of the sites at which the plants had been exposed during the summer.

Within the framework of a European network for air quality assessment through using bioindicator plants, Trad-MCN was used to monitor urban areas in ten cities (Klumpp et al., 2006). The results obtained revealed that the genotoxic effects were higher in areas with heavier traffic. It was concluded that this test was a suitable tool for detecting local hot spots' of mutagenic air pollution in urban areas.

The correlation between micronucleus frequency in tetrads of Tradescantia and the adjusted mortality rates for cardiovascular and respiratory diseases and cancer was investigated by Mariani et al. (2009). Their study included biomonitoring at 28 sites with different degrees of atmospheric pollution in the city of São José dos Campos (Brazil) over a five-month period. 
The higher micronucleus frequencies observed were in the plants that were exposed in areas of heavy traffic and in areas close to a petrochemical complex. Significant associations were detected between micronucleus frequency and the mortality rate due to cardiovascular diseases and cancer.

\subsubsection{Tradescantia pallida (Rose) Hunt. cv. purpurea Boom}

Biomonitoring studies on plants of the species T. pallida have mostly been conducted by Brazilian researchers. The results obtained have confirmed the results from pioneering studies that showed that naturally occurring plants of this species are as sensitive as clones (Suyama et al., 2002).

Batalha et al. (1999) used seedlings of T. pallida to evaluate the air quality in the city of São Paulo (Brazil), which is the largest urban center in the southern hemisphere. The seedlings were exposed to air samples collected from the city center that had been diluted in distilled water at concentrations of 15 and $30 \mathrm{mg} / \mathrm{l}$. The micronucleus frequency in the plants exposed to the more concentrated solution was significantly greater than the frequency observed in the plants exposed to the lower concentration, thus demonstrating the genotoxic effects from the atmospheric pollution in this city. The air quality in the city of São Paulo was also evaluated by Guimarães et al. (2000) using this methodology and their results showed the effectiveness of $T$. pallida plants for detecting the genotoxic effects from atmospheric pollution.

Carvalho-Oliveira et al. (2005) also conducted a biomonitoring study using T. pallida plants in the city of São Paulo and demonstrated that diesel fuel burned by automotive vehicles induced genotoxicity. These authors evaluated occurrences of micronuclei over a three-day period during a strike by bus drivers and one week after the strike ended. The results obtained showed that the micronucleus frequency was significantly higher during the strike. Carreras et al. (2006) investigated the genotoxicity of atmospheric pollution in the city of Córdoba (Argentina) between October 2004 and April 2005. T. pallida plants were exposed at three sites: one in the city center, characterized by heavy traffic of automotive vehicles; another on the university campus, located along a side road with heavy traffic of gasoline and diesel-powered vehicles (buses and trucks); and a third site in a residential area without significant pollution sources. Twenty young T. pallida inflorescences were collected from each sampling site in November, February and April. The lowest micronucleus frequencies were observed in the plants placed in the residential area. Similar results using the same methodology were obtained by Prajapati \& Tripathi (2008) in a study on air quality biomonitoring in the city of Varanasi (India).

The results obtained through studies carried out by our team, in cities in the state of Bahia (Brazil) have systematically indicated the effectiveness of Trad-MCN using T. pallida, both for assessing the genotoxic effects consequent to air pollution originating from automotive vehicles and for assessing soil contaminants. Higher micronucleus frequencies associated with air contamination due to automotive vehicles were detected even in cities with low traffic flows.

The air quality in Senhor do Bonfim, a small city in the state of Bahia (Brazil), was evaluated by Andrade Júnior et at. (2008). This biomonitoring study involved exposure of T. pallida in two areas with different traffic levels: (1) on the Lomanto Junior highway, close to the ring road, where there is heavy traffic of cars, trucks and buses; and (2) in Praça Nova do Congresso, a public square located in the city center, where the traffic is less intense. The 
control consisted of plants that were kept in a traffic-free area. Young inflorescences were gathered every month over a 12-month period. The statistical analysis on the results showed that the micronucleus frequency was significantly higher in the exposed plants than in the controls. However, there was no statistically significant difference between the two exposure sites.

Air monitoring in the city of Feira de Santana, the second largest urban center in the state of Bahia (Brazil) was carried out by Meireles et al. (2009) using Trad-MCN with T. pallida between February 2006 and December 2007. Two types of monitoring were undertaken in this study: active and passive. Three localities with different traffic flows were chosen for testing: (1) the Campo Limpo traffic circle, which according to data that we collected had a traffic load of approximately 8200 vehicles/hour, mainly consisting of buses and trucks; (2) Getúlio Vargas Avenue which also had heavy traffic, although less than at Campo Limpo (3500 vehicles/hour according to data from the municipal authorities of Feira de Santana); and (3) an area with very low vehicle movement (about 10 vehicles/day, according to our observations during the study period).

Inflorescences were collected on a monthly basis from plants growing in these locations, under both passive and active monitoring regimes. Micronucleus occurrences were found to be proportional to vehicle flows under both monitoring regimes, while the plants under active monitoring showed greater sensitivity to atmospheric contamination.

\section{Conclusion}

From this presentation, it can be seen that, despite certain limitations, Trad-MCN carried out using plants or clones of T. pallida is an important tool for biomonitoring of atmospheric pollution.

\section{Acknowledgement}

We thank Feira de Santana State University, Bahia State University and FAPESB for their financial support for our research.

\section{References}

Alves, E.; Giusti, P.; Domingos, M.; Saldiva, P.; Guimarães, E. \& Lobo D. (2001). Estudo anatômico foliar do clone híbrido 4430 de Tradescantia: alterações decorrentes da poluição aérea urbana. Revista Brasileira de Botânica, Vol. 24, No. 4, December 2001, pp. 567-576, ISSN 0100-8404

Andrade Júnior, S.; Santos Júnior, J.; Oliveira, J.; Cerqueira, E. \& Meireles, J. (2008). Micronúcleos em tétrades de Tradescantia pallida (Rose) Hunt. cv. purpurea Boom: alterações genéticas decorrentes de poluição aérea urbana. Acta Scientiarum: Biological Sciences, Vol. 30, No. 3, July-September 2008, pp. 295-301, ISSN 16799283

Arutyunyan, R.; Pogosyan, V.; Simonyan, E.; Atoyants, A. \& Djigardjian, E. (1999). In situ monitoring of the ambient air around the chloroprene rubber industrial plant using the Tradescantia-stamen-hair mutation assay. Mutation Research/Fundamental and Molecular Mechanisms of Mutagenesis, Vol. 426, No. 2, May 1999, pp. 117-120, ISSN 1386-1964 
Batalha, J.; Guimarães, E.; Lobo, D.; Lichtenfels, A.; Deur, T.; Carvalho, H.; Alves, E.; Domingos, M.; Rodrigues, G. \& Saldiva, P. (1999). Exploring the clastogenic effects of air pollutants in São Paulo (Brazil) using the Tradescantia micronuclei assay. Mutation Research, Vol. 426, No. 2, May 1999, pp. 229-232, ISSN 0027-5107

Beelen, R.; Hoek, G.; van den Brandt P.; Goldbohm, R.; Fischer, P.; Schouten, L.; Armstrong. B. \& Brunekreef, B. (2008). Long-term exposure to traffic-related air pollution and lung cancer risk. Epidemiology, Vol. 19, No. 5, September 2008, pp. 702-710, ISSN 1531-5487

Brunekreef, B, Holgate, ST. (2002). Air pollution and health. Lancet, Vol. 360, No. 9341, October 2002, pp. 1233-1242, INSS 0140-6736

Carreras, H.; Pignata, M. \& Saldiva P. (2006). In situ monitoring of urban air in Córdoba, Argentina using the Tradescantia-micronucleus (Trad-MCN) bioassay. Atmospheric Environment, Vol. 40, No. 40, December 2006, pp. 7824-7830, ISSN 1352-2310

Carvalho, H. (2005). A Tradescantia como bioindicador vegetal na monitoração dos efeitos clastogênicos das radiações ionizantes. Radiologia Brasileira, Vol. 38, No. 6, November-December 2005, pp. 459-462, ISSN 0100-3984

Carvalho-Oliveira, R.; Pozo, R.; Lobo, D.; Lichtenfels, A.; Martins-Junior, H.; Bustilho, J.; Saiki, M.; Sato, I. \& Saldiva, PH. (2005) Diesel emissions significantly influence composition and mutagenicity of ambient particles: a case study in São Paulo, Brazil. Environmental Research, Vol. 98, No. 1, May 2005, pp. 1-7, ISSN 0013-9351

Cohen, J.; Carlson, G.; Charnley, G.; Coggon, D.; Delzell, E.; Graham, J.; Greim, H.; Krewski, D.; Medinsky, M.; Monson, R.; Paustenbach, D.; Petersen, B.; Rappaport, S.; Rhomberg, L.; Ryan, P. \& Thompson, K. (2002). A comprehensive evaluation of the potential health risks associated with occupational and environmental exposure to styrene. Journal of Toxicology and Environmental Health, Part B: Critical Reviews, Vol. 5, No. 1, January-June 2002, pp. 1-265, ISSN 1521-6950

Coronas, M.; Horn, R.; Ducatti, A.; Rocha, J. \& Varga, M. (2008). Mutagenic activity of airborne particulate matter in a petrochemical industrial area. Mutation Research/Genetic Toxicology and Environmental Mutagenesis, Vol. 650, No. 2, February 2008, pp. 196-201, ISSN 1383-5718

Eitan, O.; Yuval; Barchana, M.; Dubnov, J.; Linn, S.; Carmel, Y. \& Broday, D. (2010). Spatial analysis of air pollution and cancer incidence rates in Haifa Bay, Israel. Science of the Total Environment, Vol. 408, No. 20, September 2010, pp. 4429-4439, ISSN 0048-9697

Emmerling-Thompson, M. \& Nawrocky, M. (1982). Evidence of gametic mutation for flower color in Tradescantia. Environmental and Experimental Botany, Vol. 22, No. 4, November 1982, pp. 403-408, ISSN 0098-8472

Ennever, F.; Andreano, G. \& Rosenkranz, H. (1988). The ability of plant genotoxicity assays to predict carcinogenicity. Mutation Research, Vol. 205, No. 1-4, May-August 1988, pp. 95-105, ISSN 0027-5107

Falistocco, E.; Torricelli, R.; Feretti, D.; Zerbini, I.; Zani, C. \& Monarca S. (2000). Enhancement of micronuclei frequency in the Tradescantia/micronuclei test using a long recovery time. Hereditas, Vol. 133, No. 2, May 2000, pp. 171-174, ISSN 00180661

Fomin, A. \& Hafner, C. (1998). Evaluation of genotoxicity of emissions from municipal waste incinerators with Tradescantia-micronucleus bioassay (Trad-MCN). Mutation 
Research/Genetic Toxicology and Environmental Mutagenesis, Vol. 414, No. 1-3, May 1998, pp. 139-148, ISSN 1383-5718

Gichner, T. \& Velemínský, J. (1999). Monitoring the genotoxicity of soil extracts from two heavily polluted sites in Prague using the Tradescantia stamen hair and micronucleus (MNC) assays. Mutation Research/ Fundamental and Molecular Mechanisms of Mutagenesis, Vol. 426, No. 2, May 1999, pp. 163-166, ISSN 1386-1964

Grant, W.; Lee, H.; Logan, D. \& Salamone, M. (1992). The use of Tradescantia and Vicia faba bioassays for the in situ detection of mutagens in an aquatic environment. Mutation Research/Fundamental and Molecular Mechanisms of Mutagenesis, Vol. 270, No. 1, November 1992, pp. 53-64, ISSN 1386-1964

Guimarães, E.; Domingos, M.; Alves, E.; Caldini, N.; Lobo, D.; Lichtenfels A. \& Saldiva, P. (2000). Detection of the genotoxicity of air pollutants in and around the city of São Paulo (Brazil) with the Tradescantia-micronucleus (Trad-MCN) assay. Environmental and Experimental Botany, Vol. 44, No. 1, August 2000, pp. 1-8, ISSN 0098-8472

Hanahan, D. \& Weinberg, R. (2000). The hallmarks of cancer. Cell, Vol. 100, No. 1, January 2000, pp. 57-70, ISSN 0092-8674

Holland, N.; Bolognesi, C.; Kirsch-Volders, M.; Bonassi, S.; Zeiger, E.; Knasmueller, S. \& Fenech, M. (2008). The micronucleus assay in human buccal cells as a tool for biomonitoring DNA damage: the HUMN project perspective on current status and knowledge gaps. Mutation Research, Vol. 659, No. 1-2, July-August 2008, pp. 93-108, INSS 0027-5107

Ianistcki, M.; Dallarosa, J.; Sauer, C.; Teixeira, C. \& da Silva, J. (2009). Genotoxic effect of polycyclic aromatic hydrocarbons in the metropolitan area of Porto Alegre, Brazil, evaluated by Helix aspersa (Müller, 1774). Environmental Pollution, Vol. 157, No. 7, July 2009, pp. 2037-2042, ISSN 0269-7491

Isidori, M.; Ferrara, M.; Lavorgna, M.; Nardelli A. \& Parrella, A. (2003). In situ monitoring of urban air in Southern Italy with the Tradescantia micronucleus bioassay and semipermeable membrane devices (SPMDs). Chemosphere,Vol. 52, No. 1, July 2003, pp. 121-126, ISSN 0045-6535

Joly, Aylthon Brandão. (1998). Botânica: introdução a taxonomia vegetal (12th edition), Nacional, ISBN 8504002314, São Paulo

Kapka, L.; Zemła, B.; Kozłowska, A.; Olewinska, E. \& Pawlas, N. (2009). Jakość powietrza atmosferycznego a zapadalność na nowotwory płuc w wybranych miejscowościach i powiatach województwa śląskiego. Przeglad Epidemiologiczny, Vol. 63, No. 3, March 2009, pp. 439-444, ISSN 0033-2100

Kawanaka, Y.; Matsumoto, E.; Sakamoto, K. \& Yun, S. (2011). Estimation of the contribution of ultrafine particles to lung deposition of particle-bound mutagens in the atmosphere. Science of the Total Environment, Vol. 409, No. 6, February 2011, pp. 1033-1038, ISSN 0048-9697

Kawanishi, M.; Watanabe, T.; Hagio, S.; Ogo, S.; Shimohara, C.; Jouchi, R.; Takayama, S.; Hasei, T.; Hirayama, T.; Oda, Y. \& Yagi, T. (2009). Genotoxicity of 3,6dinitrobenzo[e]pyrene, a novel mutagen in ambient air and surface soil, in mammalian cells in vitro and in vivo. Mutagenesis, Vol. 24, No. 3, May 2009, pp. 279-284, ISSN 1464-3804 
Klumpp, A.; Ansel, W.; Fomin, A.; Schnirring, S. \& Pickl, C. (2004). Influence of climatic conditions on the mutations in pollen mother cells of Tradescantia clone 4430 and implications for the Trad-MCN bioassay protocol. Hereditas, Vol. 141, No. 2, May 2004, pp. 142-148, ISSN 0018-0661

Klumpp, A.; Ansel, W.; Klumpp, G.; Calatayud, V.; Carrec, J.; He, S.; Peñuelas, J.; Ribas, A.; RoPoulsen, H.; Rasmussen, S.; Sanz, M. \& Vergne, F. (2006). Tradescantia micronucleus test indicates genotoxic potential of trafic emissions in European cities. Environmental Pollution, Vol. 139, No. 3, February 2006, pp. 515-526, ISSN 0269-7491

Lorenzi, H. \& Souza, HM. (2008). Plantas ornamentais no Brasil: arbustivas, herbáceas e trepadeiras (4th edition), Instituto Plantarum, ISBN 9788586714306, São Paulo

Ma, T.; Sparrow, A.; Schairer, L. \& Nauman, A. (1978). Effect of 1,2-dibromoethane (DBE) on meiotic chromosomes of Tradescantia. Mutation Research/Genetic Toxicology, Vol. 58, No.2-3, November 1978, pp. 251-258, ISSN 1383-5718

Ma, T. (1981). Tradescantia micronucleus bioassay and pollen tube chromatid aberration test for in situ monitoring and mutagen screening. Environmental Health Perspectives, Vol. 37, No 1, January 1981, pp. 85-90, ISSN 0091-6765

Ma, T. \& Grant, W. (1982) The Tradescantia - adventurous plants. The herbarist, Vol. 48, April 1982, pp. 36-44, ISSN 0740-5979

Ma, T.; Cabrera G.; Cebulska-Wasilewska, A.; Chen, R.; Loarca, F.; Vandenberg, A. \& Salamone, M. (1994). Tradescantia stamen hair mutation bioassay. Mutation Research,Vol. 310, No. 2, October 1994, pp. 210-220, ISSN 0027-5107

Ma, T.; Xu, C.; Liao, S.; McConnell, H.; Jeong, B. \& Won, C. (1996). In situ monitoring with the Tradescantia bioassays on the genotoxicity of gaseous emissions from a closed landfill site and an incinerator. Mutation Research, Vol. 359, No. 1, January 1996, pp. 39-52, ISSN 0027-5107

Marcondes, Ayrton Cesar. (1993). Programas de saúde (4th edition), Atual, ISBN 85-7056238-1, São Paulo

Mariani, R.; Jorge, M.; Pereira, S.; Melione, L.; Carvalho-Oliveira, R.; Ma, T. \& Saldiva, P. (2009). Association between micronuclei frequency in pollen mother cells of Tradescantia and mortality due to cancer and cardiovascular diseases: a preliminary study in Sao José dos Campos, Brazil. Environmental Pollution, Vol. 157, No. 6, June 2009, pp. 1767-1770, ISSN 0269-7491

Meireles, J.; Rocha, R.; Costa-Neto, A. \& Cerqueira, E. (2009). Genotoxic effects of vehicle traffic pollution as evaluated by micronuclei test in tradescantia (Trad-MCN). Mutation Research/ Fundamental and Molecular Mechanisms of Mutagenesis, Vol. 675, No. 1-2, April 2009, pp. 46-50, ISSN 1386-1964

Minouflet, M.; Ayrault, S.; Badot, P.; Cotelle, S. \& Ferard, J. (2005). Assessment of the genotoxicity of $137 \mathrm{Cs}$ radiation using Vicia-micronucleus, Tradescantiamicronucleus and Tradescantia-stamen-hair mutation bioassays. Journal of Environmental Radioactivity, Vol. 81, No. 2-3, July 2005, pp. 143-153, ISSN 0265-931X

Misík, M.; Ma, T.; Nersesyan, A.; Monarca, S.; Kim, J. \& Knasmueller, S. (2011) Micronucleus assays with Tradescantia pollen tetrads: an update. Mutagenesis, Vol. 26, No. 1, January 2011, pp. 215-221, ISSN 0267-8357

Misík, M.; Micieta, K.; Solenská, M.; Misíková, K.; Pisarcíková, H. \& Knasmüller, S. (2007). In situ biomonitoring of the genotoxic effects of mixed industrial emissions using 
the Tradescantia micronucleus and pollen abortion tests with wild life plants: demonstration of the efficacy of emission controls in an eastern European city. Environmental Pollution, Vol. 145, No. 2, January 2007, pp. 459-466, ISSN 0269-7491

Monarca, S.; Ferreti, D.; Zanardini, A.; Falistocco, E., \& Nardi, G. (1999). Monitoring of mutagens in urban air sample. Mutation Research, Vol. 426, No. 2, May 1999, pp. 189-192, ISSN 0027-5107

Peluso, M.; Srivatanakul, P.; Munnia, A.; Jedpiyawongse, A.; Meunier, A.; Sangrajrang S.; Piro. S.; Ceppi, M. \& Boffetta P. (2008). DNA adduct formation among workers in a Thai industrial estate and nearby residents. Science of The Total Environment, Vol. 389, No. 2-3, February 2008, pp. 283-288, ISSN 0048-9697

Perera, F.; Hemminki, K.; Jedrychowski W.; Whyatt R.; Campbell U.; Hsu Y.; Santella,R.; Albertini, R.; \& O'Neill, J. (2002). In utero DNA damage from environmental pollution is associated with somatic gene mutation in newborns. Cancer Epidemiology Biomarkers \& Prevention, Vol. 11, No. 10, October 2002, pp. 1134-1137, ISSN 1538-7755

Prajapati, S. \& Tripathi, B. (2008). Assessing the genotoxicity of urban air pollutants in Varanasi City using Tradescantia micronucleus (Trad-MCN) bioassay. Environment International, Vol. 34, No. 8, November 2008, pp. 1092-1096, ISSN 0160-4120

Rodrigues, G.; Madkour, A. \& Weinstein, L. (1996). Genotoxic activity of ozone in Tradescantia. Environmental and Experimental Botany, Vol. 36, No. 1, May 1996, pp. 45-50, ISSN 0098-8472

Rodrigues, G.; Ma, T.; Pimentel, D. \& Weinstein, LH. (1997). Tradescantia bioassays as monitoring systems for environmental mutagenesis: A review. Critical Reviews in Plant Sciences, Vol. 16, No. 4, July 1997, pp. 325-359, ISSN 0735-2689

Rodrigues, Geraldo Stachetti. (1999). Bioensaios de toxicidade genética com Tradescantia (1th edition), Embrapa Meio Ambiente, ISSN 1516-4691, Jaguariúna

Shima, N. \& Ichikawa, S. (1994). Sinergism detected among methyl methanesulfonate, ethyl methanesulfonate and X-rays in inducing somatic mutations in the stamen hair of Tradescantia clone BNL 4430. Environmental end Experimental Botany.Vol. 34, No. 4, October 1994, pp. 393-406, INSS 0098-6472

Suyama, F.; Guimarães, E.; Lobo, D.; Rodrigues, G.; Domingos, M.; Alves, E.; Carvalho, H. \& Saldiva, P. (2002). Pollen mother cells of Tradescantia clone 4430 and Tradescantia pallida var. purpurea are equally sensitive to the clastogenic effects of X-rays. Brazilian Journal of Medical and Biological Research, Vol. 35, No. 1, January 2002, pp. 127-129, ISSN 0100-879X

Traversi, D.; Degan, R.; De Marco, R.; Gilli, G.; Pignata, C.; Ponzio, M.; Rava, M.; Sessarego, F.; Villani, S. \& Bono, R. (2008). Mutagenic properties of PM2.5 air pollution in the Padana Plain (Italy) before and in the course of XX Winter Olympic Games of "Torino 2006". Environment International, Vol. 34, No. 7, October 2008, pp. 966-970, ISSN 0160-4120

Traversi, D.; Degan, R.; De Marco, R.; Gilli, G.; Pignata, C.; Villani, S. \& Bono, R. (2009). Mutagenic properties of PM2.5 urban pollution in the northern Italy: the nitrocompounds contribution. Environment International, Vol. 35, No. 6, April 2009, pp. 905-910, ISSN 0160-4120

Trédaniel, J.; Aarab-Terrisse, S.; Teixeira, L.; Savinelli, F.; Fraboulet, S.; Gossot, D. \& Hennequin, C. (2009). Pollution atmosphérique et cancer bronchique : données 
épidémiologiques. Revue des maladies respiratoires, Vol. 26, No. 4, April 2009, pp. 437445, ISSN 0761-8425

Underbrink, A.; Schairer, L. \& Sparrow, A. (1973). The biophysical properties of 3.9-GeV nitrogen ions. V. Determinations of the relative biological effectiveness for somatic mutations in Tradescantia. Radiation Research. Vol. 55, No. 3, September 1973, pp. 437-446, ISSN 0033-7587

Villarini, M.; Fatigoni, C.;Dominici, L.;Maestri, S.;Ederli, L.; Pasqual, S.; Monarca, S. \& Moretti, M. (2009). Assessing the genotoxicity of urban air pollutants using two in situ plant bioassays. Environmental Pollution, Vol. 157, No 12, December 2009, pp. 3354-3356, ISSN 0269-7491

Vineis, P.; Hoek, G.; Krzyzanowski, M.; Vigna-Taglianti, F.; Veglia, F.; Airoldi, L.; Overvad, K.; Raaschou-Nielsen, O.; Clavel-Chapelon, F.; Linseisen, J.; Boeing, H.; Trichopoulou, A.; Palli, D.; Krogh, V.; Tumino, R.; Panico, S.; Bueno-De-Mesquita, H.; Peeters, P.; Lund, E.; Agudo, A.; Martinez, C.; Dorronsoro, M.; Barricarte, A.; Cirera, L.; Quiros, J.; Berglund, G.; Manjer, J.; Forsberg, B.; Day, N.; Key, T.; Kaaks, R.; Saracci, R. \& Riboli, E. (2007). Lung cancers attributable to environmental tobacco smoke and air pollution in non-smokers in different European countries: a prospective study. Environmental Health, Vol. 6, No. 7, February 2007, pp. 1-7 ISSN 1476-069X

Wada, M.; Kido, H.; Kishikawa, N.; Tou, T.; Tanaka, M.; Tsubokura, J.; Shironita, M.; Matsui, M.; Kuroda, N. \& Nakashim, K. (2001). Assessment of air pollution in Nagasaki city: determination of polycyclic aromatic hydrocarbons and their nitrated derivatives, and some metals. Environmental Pollution, Vol. 115, No. 1, November 2001, pp. 139-147, ISSN 0269-7491

Watson, L. \& Dallwitz, M. (1992) onwards. The families of flowering plants: descriptions, illustrations, identification, and information retrieval. Version: 4th February 2011. http://delta-intkey.com

Yauk, C.; Polyzos, A.; Rowan-Carroll, A.; Somers, C.; Godschalk, R.; Van Schooten, F.; Berndt, M.; Pogribny, I.; Koturbash, I.; Williams, A.; Douglas, G. \& Kovalchuk, O. (2008). Germ-line mutations, DNA damage, and global hypermethylation in mice exposed to particulate air pollution in an urban/industrial location. Proceedings of the National Academy of Sciences. Vol. 105, No. 2, January 2008, pp. 605-610. ISSN 1091-6490 


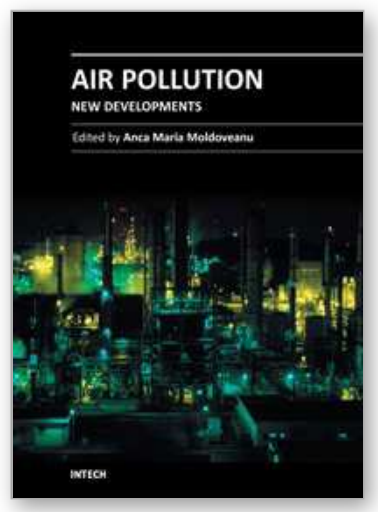

\author{
Air Pollution - New Developments \\ Edited by Prof. Anca Moldoveanu
}

ISBN 978-953-307-527-3

Hard cover, 324 pages

Publisher InTech

Published online 06, September, 2011

Published in print edition September, 2011

Today, an important issue is environmental pollution, especially air pollution. Due to pollutants present in air, human health as well as animal health and vegetation may suffer. The book can be divided in two parts. The first half presents how the environmental modifications induced by air pollution can have an impact on human health by inducing modifications in different organs and systems and leading to human pathology. This part also presents how environmental modifications induced by air pollution can influence human health during pregnancy. The second half of the book presents the influence of environmental pollution on animal health and vegetation and how this impact can be assessed (the use of the micronucleus tests on TRADESCANTIA to evaluate the genotoxic effects of air pollution, the use of transplanted lichen PSEUDEVERNIA FURFURACEA for biomonitoring the presence of heavy metals, the monitoring of epiphytic lichen biodiversity to detect environmental quality and air pollution, etc). The book is recommended to professionals interested in health and environmental issues.

\title{
How to reference
}

In order to correctly reference this scholarly work, feel free to copy and paste the following:

José Roberto Cardoso Meireles and Eneida de Moraes Marcilio Cerqueira (2011). Use of the Micronucleus Test on Tradescantia (Trad-MCN) to Evaluate the Genotoxic Effects of Air Pollution, Air Pollution - New Developments, Prof. Anca Moldoveanu (Ed.), ISBN: 978-953-307-527-3, InTech, Available from: http://www.intechopen.com/books/air-pollution-new-developments/use-of-the-micronucleus-test-ontradescantia-trad-mcn-to-evaluate-the-genotoxic-effects-of-air-pollu

\section{INTECH}

open science | open minds

\section{InTech Europe}

University Campus STeP Ri

Slavka Krautzeka 83/A

51000 Rijeka, Croatia

Phone: +385 (51) 770447

Fax: +385 (51) 686166

www.intechopen.com

\section{InTech China}

Unit 405, Office Block, Hotel Equatorial Shanghai

No.65, Yan An Road (West), Shanghai, 200040, China 中国上海市延安西路65号上海国际贵都大饭店办公楼 405 单元

Phone: +86-21-62489820

Fax: $+86-21-62489821$ 
(C) 2011 The Author(s). Licensee IntechOpen. This chapter is distributed under the terms of the Creative Commons Attribution-NonCommercialShareAlike-3.0 License, which permits use, distribution and reproduction for non-commercial purposes, provided the original is properly cited and derivative works building on this content are distributed under the same license. 